\title{
Microbial Waste and Spoilage of Food and Their Detection with Ecofiendly Routine Check Up
}

\section{Rajesh Laik*}

CFTRI- Mysore, Food Preneur, Afdstilife member, Karnataka, India

*Corresponding Author: Rajesh Laik, CFTRI- Mysore, Food Preneur, Afdstilife member, Karnataka, India.

DOI: 10.31080/ASMI.2020.03.0515

Keywords: Ecofiendly; Agriclinics; Microbial Biodiversity; Climatechange
Received: January 18, 2020

Published: February 08, 2020

(C) All rights are reserved by Rajesh Laik.
First of all, monitor the food storage after purchasing from the market their storage and monitoring of this food their infection with microbial biodiversity check their spoilage natural conditioning and artificial conditioning natural outside of refrigeration condition under sunlight, ecofriendly climatic condition and their suitability in environment and accordingly select their food value their cultivation at airfield monitoring the crop with Agri clinics and do their marketing at field condition, to give a healthy competitive market from home to market or field to market if no lab is available for testing then what do the farmer need by just monitor the vegetable and crops create awareness among farmer with this processing technology before selling and eating so that no gastric problem arises. but if inside Refrigeration condition we are wasting the crop health with mor microbial biodiversity and spoilage we need to check them always hen global warming will be solved to mitigate the ozone hole.

Find solution to farmers in their eating habit of crop and cooking methodology thus our health and marketing remains ecofriendly. People will come to know about flooding habit by way of turnover of their business and marketing of crops and their processing technology.

To summarize this once again this will be a valuable protocol to develop the Agri processing and food technology in our day-day to strategy of marketing consumption and taking food minimize waste and develop organic farming. In this protocol I want to create awareness in society that the use of refrigerator will be limited ac- cording to climate and season change. and the consumption chlorofluorocarbon will be reduced, ecofiendly solution will be achieved and people will like this method and can chose alternat option to save food with solar technology. Compressor will be replaced by solar inverter. automated biosensor will monitor the refrigeration technology. Hence the pollution will be in control.

\section{Assets from publication with us}

- Prompt Acknowledgement after receiving the article

- Thorough Double blinded peer review

- Rapid Publication

- Issue of Publication Certificate

- High visibility of your Published work

Website: https://www.actascientific.com/

Submit Article: https://www.actascientific.com/submission.php Email us: editor@actascientific.com

Contact us: +919182824667 